University of Nebraska - Lincoln

DigitalCommons@University of Nebraska - Lincoln

Faculty Publications: Department of Teaching, Department of Teaching, Learning and Teacher Learning and Teacher Education

Education

2020

\title{
Transformative Interviewing and the Experiences of Multilingual Learners not Labeled “ELL” in US Schools
}

\author{
Theresa Catalano \\ University of Nebraska-Lincoln, tcatalano2@unl.edu \\ Lydiah Kananu Kiramba \\ University of Nebraska-Lincoln, Ikiramba2@unl.edu \\ Kara Mitchell Viesca \\ University of Nebraska - Lincoln, kara.viesca@unl.edu
}

Follow this and additional works at: https://digitalcommons.unl.edu/teachlearnfacpub

Part of the Curriculum and Instruction Commons, and the Teacher Education and Professional

Development Commons

Catalano, Theresa; Kiramba, Lydiah Kananu; and Viesca, Kara Mitchell, "Transformative Interviewing and the Experiences of Multilingual Learners not Labeled "ELL" in US Schools" (2020). Faculty Publications: Department of Teaching, Learning and Teacher Education. 399.

https://digitalcommons.unl.edu/teachlearnfacpub/399

This Article is brought to you for free and open access by the Department of Teaching, Learning and Teacher Education at DigitalCommons@University of Nebraska - Lincoln. It has been accepted for inclusion in Faculty Publications: Department of Teaching, Learning and Teacher Education by an authorized administrator of DigitalCommons@University of Nebraska - Lincoln. 


\title{
Transformative interviewing and the experiences of multilingual learners not labeled "ELL" in US schools
}

\author{
Theresa Catalano, Lydiah Kananu Kiramba, \\ and Kara Viesca \\ University of Nebraska-Lincoln \\ Corresponding author - Theresa Catalano tcatalano2@unl.ed Department of Teaching, Learning \\ and Teacher Education University of Nebraska-Lincoln, Henzlik 118, Lincoln, NE 68588.
}

\begin{abstract}
Recent research has documented the ways that schools adapt to increasingly multilingual and multicultural student bodies. This qualitative study explores the schooling experiences of nine K-12 multilinguals not identified as English language learners in US schools. Using "deep interviewing" strategies, the authors expose the racializing function of language, but also semiotic processes such as markedness, iconicity, and erasure and sociological concepts such as habitus that are revealed through analysis of the participants' discourse about language and schooling. Additionally, the authors illustrate how transformative interviewing practices can spur development of learners' own agency in creating more equitable learning contexts for themselves.
\end{abstract}

Published in Bilingual Research Journal (2020)

doi 10.1080/15235882.2020.1738287

Copyright (C) 2020 the National Association for Bilingual Education; published by Routledge/ Taylor \& Francis Group. Used by permission.

Theresa Catalano, PhD, is an Associate Professor of Second Language Education/Applied Linguistics at the University of Nebraska- Lincoln. Her research focuses on education and migration, multilingualism, dual language education, and critical language studies.

Lydiah Kananu Kiramba, PhD, is an Assistant Professor of Educational Linguistics in the Department of Teaching, Learning and Teacher Education at the University of NebraskaLincoln. Her research focuses on communicative practices of multilingual and multicultural students in super-diverse classrooms and literacies of Black immigrant children in $\mathrm{K}-12$ classrooms.

Kara Viesca, PhD, is an Associate Professor of Teaching, Learning and Teacher Education at the University of Nebraska Lincoln. Her scholarship focuses on advancing equity in the policy and practice of educator development, particularly for teachers of multilingual learners. 
$\mathrm{D}$ ue to globalization, increased mobility, and a variety of other factors, today's classrooms are increasingly diverse. As a consequence of this phenomena, much recent research has studied the ways that teachers and schools adapt to their increasingly multilingual and multicultural student bodies (García \& Kleifgen, 2010; García \& Sylvan, 2011; Janzen, 2008; Lucas, Villegas, \& Freedson-Gonzalez, 2008) as well as ways teachers can draw on the linguistic and cultural resources of their students in their teaching (Bruen \& Kelly, 2016; Cummins, 2009; García, Johnson, Seltzer, \& Valdés, 2017; García \& Kleyn, 2016; Menken, Kleyn, \& Chae, 2012).

In the United States, much of this research has concentrated on students officially identified as "English language learners (ELLs)" meaning they have taken a placement test which identifies them as needing English language support. A few studies (e.g., Brooks, 2015; Menken et al., 2012), have examined the characteristics of students described as long-term "ELLs" (LTELLs) who were born in the United States, or migrated to the US as of school age, but speak a language other than English at home, and have yet to shed the "ELL" label despite years of being educated in US schools (for a strong critique of the LTELL label, see Brooks, 2019). No studies that we found examined student perspectives of multilingual populations in the United States in which the students have exited English language support programs early or were never identified as "ELL".

The United States has a long, rich, and contested multilingual history in which policy discourses have varied between monolingual and multilingual views of the role of linguistic and cultural diversity in schools (see de Jong, 2013 for a detailed account of this history). Recently, the multilingual learner ${ }^{1}$ population in the US has been largely constructed in terms of English proficiency, and these students have often been either situated as "academic failures" (Mitchell, 2012, p. 2) or because they have reached higher levels of English proficiency, they are invisible or abandoned in the system (Stake, 2000).

When teachers come to school, they often bring with them a set of ideologies about language which they are unconscious of, and that transfer over to the way they think about and treat their multilingual

1. We use "multilingual learners" to refer to speakers of two or more languages (and a number of varieties of each), since this term positively recognizes their heteroglossic language practices (García, 2009a), but is also inclusive of students such as our participants, who are not recognized as needing language support. 
students (Flores \& Rosa, 2015). This “deficit perspective of multilingual learners makes it difficult for educators and administrators to see the linguistic skills and strengths multilingual learners have" (Mitchell, 2012, p. 13). Moreover, when multilingualism of students is recognized as a strength, this recognition is often "not distributed evenly across all race and language backgrounds", (Mitchell, 2013, p. 351). In addition, students that are simultaneous multilinguals (meaning they have acquired one or more languages and the language of schooling roughly at the same time), or learners that quickly learn English and catch up to their peers in content areas become "invisible in policy and practice as they are then treated as if they are monolingual and monocultural" (Mitchell, 2012, p, 13). As a consequence, the multiple worlds in which the learners participate are ignored (Chhuon, Hudley, Brenner, \& Macias, 2010).

As such, the present study aims to shed light on the experiences of multilingual learners in US K-12 schools that (for whatever reason), exited English language support programs early or never participated in them. Recognizing that participants can speak for themselves and hence, represent their own lives (Spack, 1997, p. 773), we chose to interview nine multilingual learners in US K-12 schools along with their parents. Our study was guided by the following research questions:

(1) What are the experiences of multilingual learners NOT identified as "ELL" in US K-12 schools?

(2) How do these experiences vary depending on a variety of factors including race/ethnicity, language, and societal ideologies/ attitudes?

(3) How do the learners (and their parents) perceive of the way that schools both acknowledge and draw on their multilingualism in their learning?

Adapting a transformative interview framework (Greenfield, 2010), we aim not only to find out about multilingual learner perspectives regarding their multilingualism and schooling, but to raise participant awareness about their own agency in utilizing their home languages for learning. Although our focus is on the multilingual learners, we occasionally included input from their mothers in order to provide a richer understanding of the learning contexts of the participants and because they chose to participate along with their child in the interviews. 


\section{Invisible multilingualism in the classroom}

Research has demonstrated several advantages of encouraging home language use in the classroom (Park, 2013; Reyes de la Luz, 2012; Kiramba \& Harris, 2019). Park (2013) showed how a student used a dual frame of reference to critically analyze her learning contexts in Guinea and the US. Park concluded that such dual frames of reference may be leveraged to support students' inquiries as they navigate school subjects, and to provide them access into texts.

Although the use of home languages in classrooms has been acknowledged and advocated for in education for many decades, language policies often exclude unofficial languages that do not usually have a space in the school curricula (Liddicoat \& Curnow, 2014). Additionally, even in settings where multilingualism is highly promoted, other factors constrain the use of home languages. For example, Bailey and Marsden (2017) found in multilingual classrooms in the UK where multilingualism is the norm and encouraged (although this doesn't mean that nonstandard varieties and languages other than English were not stigmatized in some cases), the home language(s) was used as a bridge to English, rather than as a means of contributing to formal learning. ${ }^{2}$

Scholars have also decried the invisibility of multilingualism and multilingual literacies in the classroom (Reyes de la Luz, 2012; Kiramba, 2017). Monolingualism has remained a default educational policy in many parts of the world, (Liddicoat \& Curnow, 2014); which in turn contributes to the invisibility of minority languages. In the US, where often the dominant groups are monolingual and students come from highly diverse settings, deficit terms that ignore home languages are used, such as "ELL" (García, 2009b). Multilingual learners' assets remain invisible where students' success or failure is measured in terms of English competence (Cummins, 2009; García, 2009b). Monolingual constraints work against non-dominant languages having space or even a mention in the curriculum, (Liddicoat \& Curnow, 2014)

The invisibility of multilingualism of students who are fluent in English has unexpected impacts. Menken et al. (2012), in their study

2. Readers might note that transitional bilingual education programs in the US is built on this foundation. 
of LTELLs note there is an overlap of "ELLs" with 1.5 generation emergent bilinguals who are educated in the US but speak a language other than English at home. The invisibility of these student's multilingual nature leads to unrecognized abilities, assets, and needs thus impacting their educational opportunities and outcomes.

Additionally, the invisibility of multilingual learners' full linguistic repertoires has impacts on their perceptions of self and identity, especially true for those from minoritized language backgrounds. Reyes de la Luz (2012) decried the deficit theories that keep hurting Latinx students' academic success. Theories (e.g., translanguaging) which recognize and value the way that learners utilize all the languages in their repertoires (and encourage teachers to systematically draw on learners' full linguistic resources in their teaching) have been proposed as a way to counter deficit perspectives (Cummins, 2000; Fránquiz \& de la Luz Reyes, 1998; García \& Kleyn, 2016; González, Moll, \& Amanti, 2006; Orellana \& Reynolds, 2008).

However, invisibility of languages continues, and is notably racialized. Crump (2014) explains how this occurs, utilizing a LangCrit framework for understanding how linguistic identities intersect with racial(ized) identities and what this means for how individuals negotiate and perform them. In her study, she demonstrated how belonging is sometimes determined based on a sliding scale of visible and audible similarity or difference, or the intersection of the "subject-asseen" and "subject-as-heard" axes (Crump, 2014, p. 217). As such, language is often used as a proxy for racism (Gutiérrez \& Jaramillo, 2006; Lippi-Green, 2012). For example, if people detect any other signs of a racialized identity (such as physical appearance), they will "'hear' accent" (Hill, 2010, p. 396), and because it has largely been taboo to refuse to hire individuals (or serve them) based on race or gender, accent can often serve as grounds of discrimination due to claims that the accent interfered with the duties that needed to be performed, when in fact it didn't (Matsuda, 1991). Hence, it is difficult to separate speaking a language from its racial positioning in society (BakerBell, 2018; Flores \& Rosa, 2015). In the context of schooling, Baker-Bell (2018) argued that linguistic racism gets normalized in the classroom through certain practices. As a consequence, educators need to recognize their complicity in the reproduction of linguistic and racial inequality in schools and society. 


\section{Theoretical framework}

\section{Critical race theory and raciolinguistics}

Critical race theory (CRT) was originally developed in critical legal studies during the mid 1970 as a response to the stalled advances of the civil rights era. It was eventually introduced into education research in 1995 by Ladson-Billings and Tate. As a theoretical perspective, it offers a great deal to education research for how it centers race and illustrates how inequity in society is produced and reproduced. CRT (which is interdisciplinary) posits that racism is endemic to American life, is skeptical toward dominant legal claims of neutrality, objectivity, colorblindness and meritocracy, and challenges ahistoricism. It also insists on a contextual/historical analysis of the law and recognition of the experiential knowledge of people of color and [their] communities of origin in analyzing law and society. Finally, it works toward the end of eliminating racial oppression as part of the broader goal of ending all forms of oppression (Matsuda, Lawrence, Delgado, and Crenshaw (1993, p. 6).

While CRT obviously and valuably focuses on race, recent work has advanced our thinking considering how language is raced and race is languaged (Alim, Rickford \& Ball, 2016; Rosa, 2019). Flores and Rosa (2015) define raciolinguistic ideology as the way race plays a role in what language is deemed appropriate and how language is heard, rewarded, assessed and interpreted. Specifically, the notion of raciolinguistics explores how race is also central in issues regarding language and multilingualism, a perspective of value for our investigation. In particular, raciolinguistics shifts from focusing on the student's language practices to how those practices are interpreted by the White listener (most teachers or administrators in US public schools). These perceptions of multilingual learners are highly racialized in close connection to multilingual practices. Therefore, from a CRT and raciolinguistic perspective, the role of race in the experiences of multilingualism needs to be centrally attended to and accounted for, as we do in this study. 


\section{Theories from semiotics and sociology}

Besides CRT, several important concepts and theories from the field of semiotics and sociology are useful in understanding how the racializing of multilingualism and multilingual learners is accomplished. Semiotics is the study of signs, and the way they are interpreted or used to make meaning. As in Gal and Irvine (1995) and Shuck (2006), we also find the semiotic concepts/theories related to markedness, iconicity, and erasure, to be relevant when analyzing language ideologies as seen in our interviews. Markedness, which refers to "the asymmetrical and hierarchical relationship between two poles of any opposition" (Waugh, 1982, p. 299), is particularly useful when looking at interview data in which participants discuss language differentiation and the hierarchical way in which certain languages have more prestige and attention placed on them. It also helps explain binary pairs such as native/non-native (Shuck, 2006) and the creation of social categories and boundaries related to language (Gal \& Irvine, 1995). Iconicity in language discourse refers to the way in which certain linguistic features are linked or represent a particular social group (e.g., if I say "un chin" instead of "un poco" when I want to say "a little", Spanish speakers might assume I am from the Dominican Republic). On the other hand, erasure refers to the way in which we ignore certain historical, economic, social or linguistic phenomena because they do not fit with our imagined social order, such as when people visit other countries expecting the citizens to speak English, when they would not expect the same of themselves when others visit their country (Shuck, 2006). Another important concept (taken from the field of sociology) is habitus. According to Bourdieu, "the language of authority never governs without the collaboration of those it governs, without the help of social mechanisms capable of producing this complicity" (1977, p. 164). Habitus (which refers to deeply ingrained patterns/frames of mind that we acquire due to our life experiences which shape the way we know and engage in the world (Bourdieu, 1994, p. 182), is a useful concept to explain why participants might reproduce language ideologies and beliefs that are commonly held in the dominant society, even though they go against their own interests. In our findings section we utilize this concept to help explain language beliefs of students for which our "deep interviewing" techniques were utilized in 
order to attempt to raise their conscientização (Freire, 1974) or critical consciousness. Critical consciousness is an awareness of social and political contradictions and how to take action against oppressive elements in one's life.

\section{Method}

\section{Participants}

Nine K-12 students living in the United States at the time of the study were interviewed (along with their mothers). ${ }^{3}$ Each coauthor identified three students to interview (through their own social/ academic networks). Several of the participants were children of friends of the researchers, or former students while others were contacted via colleagues that had worked with them in some capacity in the past. Participants needed to fit the following criteria in order to be interviewed: They must 1) Be nine years of age or older4; 2) Attend school in the United States at the time of the interview 3) Speak a language/s other than English; 4) NOT be (currently) enrolled in an "ELL" program. Table 1 (below) shows the names (pseudonyms), age, grade, gender, home languages (besides English), languages studied (or studying) in school besides English, country of birth, and parents' country of birth of all nine participants.

\section{Researcher positionality}

Because researchers' various positions, roles, and identities are embedded in the outcomes of education research (Chapman, 2007) and can significantly influence access to information and participants (Visser, 2000), we now consider our own positionality. All authors identify as multilingual, and all have studied and/or taught in countries outside of their birth country.

3. As Velázquez (2018) found, mothers often take on the largest load in families in terms of language socialization/ transmission. Hence, although we asked families in general to be interviewed, only mothers ended up participating along with their children.

4. This age was determined based on cognitive/social levels we felt were necessary to understand and articulate answers to our questions. Participants varied from ages 9-17, and our study represents children at all levels of schooling (elementary, middle, high school) in the US. 
Table 1. Participant profiles.

\begin{tabular}{|c|c|c|c|c|c|c|c|}
\hline Name & Age & Grade & Gender & $\begin{array}{l}\text { Home } \\
\text { language/s }\end{array}$ & $\begin{array}{l}\text { Languages } \\
\text { studied }\end{array}$ & $\begin{array}{l}\text { Country } \\
\text { of birth }\end{array}$ & Parents' birth country \\
\hline Elena & 11 & 6th & $\mathrm{F}$ & Russian & Spanish & United States & $\begin{array}{l}\text { Mother, Kazakhstan } \\
\text { Father, United States }\end{array}$ \\
\hline Carina & 14 & 9th & $\mathrm{F}$ & French/Buamu/Dioula & Spanish & Burkina Faso & Burkina Faso \\
\hline Amanda & 17 & 11th & $\mathrm{F}$ & Portuguese & Spanish & Brazil & Brazil \\
\hline Santiago & 11 & 6th & M & Spanish & Spanish & United States & Mexico \\
\hline Aol & 13 & 8th & $\mathrm{F}$ & Nuer & Spanish & United States & South Sudan \\
\hline Dana & 10 & $5^{\text {th }}$ & $\mathrm{F}$ & Spanish & Spanish & United States & Mexico \\
\hline Meike & 9 & $5^{\text {th }}$ & $\mathrm{F}$ & German & None & United States & $\begin{array}{l}\text { Mother, Germany } \\
\text { Father, United States }\end{array}$ \\
\hline Jenni & 14 & 8th & $\mathrm{F}$ & Finnish & $\begin{array}{l}\text { French, German } \\
\text { Swedish }\end{array}$ & United States & $\begin{array}{l}\text { Mother, Finland } \\
\text { Father, United States }\end{array}$ \\
\hline Tobias & 9 & $5^{\text {th }}$ & M & German & None & United States & $\begin{array}{l}\text { Mother, American } \\
\text { Father, Germany }\end{array}$ \\
\hline
\end{tabular}

Although mothers of the participants were present and did contribute in the interviews, because our focus is on multilingual learners in K-12 schools, we did not include parent profile information.

All participants currently live in the Midwest, except for Meike, who lives in the Pacific Northwest, Tobias, who lives on the East Coast, and Jenni, who lives in the mountain west.

First author was born and raised in the United States, a White, monolingual English speaker, but later learned Italian and Spanish (and is studying Portuguese). She has three multilingual children, and one of the reasons this study came about is because she (and third author) noticed a gap in research of learners like her own children, who speak languages other than English at home, but were never classified as "ELL" and were therefore invisible in the literature, and often in the eyes of educators.

Second author is a multilingual speaker of Kimeru/Kiswahili (simultaneous bilingual), and English, born and raised in Kenya. She is a teacher educator trained in both Kenya and the US. She studies language use practices in multilingual classroom settings.

Third author was born and raised in the United States, also a White, monolingual English speaker, but learned and studied German as an exchange student in Germany as a teenager and later majored in German in college. She married into a family originally from Mexico so now also uses Spanish regularly in her home and family life.

\section{Data collection}

This qualitative study consisted of nine 6o-90 minute semi-structured interviews with multilingual learners in K-12 schools in the United 
States. Both parents of the learners were invited to attend and contribute to the interviews. In all cases, only the mothers (and sometimes younger siblings) attended. In order to better understand language beliefs of participants (and in essence, their habitus regarding language and schooling) and help them gain agency to alter them, we adopted Denzin's (2001) transformative style (as modeled and re-framed as "deep interviewing" or "transformative interviewing" in Greenfield, 2010). This type of interviewing technique reengages qualitative research "as a form of radical democratic practice" (Denzin, 2001, p. 23), and holds that words and language have a material presence in the world and that words matter, including the way that we use the language in interviews to learn about the world.

By intentionally questioning the "ingrained, unquestioned beliefs about the way the world is, the way it should be, and the way it has to be with respect to language" (Wolfram \& Schilling-Estes., 2006, p. 398), deep interviewing techniques allow the researcher to expose valuable information about learners' experiences. But also, they aid in the development of critical consciousness and a "counter-hegemonic response among linguistically dominated peoples” (Greenfield, 2010, p. 530).

In Greenfield's study which examined the privileging of colonial languages in South Africa (at the expense of Black South African students), the author used transformative or "deep interviewing" techniques to "identify the presence of more covert negative attitudes that have profound implications for educational performance" and to push his participants to decolonize their thinking about the value of their local languages which had been ingrained in them since their first experiences in school. Our interview questions can be seen in the Appendix; however, it is important to note that in keeping with the style of "deep interviewing”, particularly in terms of multilingual pedagogies, we probed and asked many follow-up questions, often repeating or re-phrasing our questions in order to elicit more reflection from the participants. We first gauged participants' initial understandings of translanguaging 5 practices and then we helped them to understand

5. As mentioned earlier, translanguaging is a "pedagogical approach that emphasizes the dynamic use of multiple languages to enhance learning and make schools more welcoming environments for multilingual children, families, and communities" (MacSwan, 2017, p. 191) and it encourages children to use language in school just like they do naturally in their homes and in the community (Van der Walt, 2015). 
what these practices might look like so that they could re-consider the idea, working against their habitus to alter their previous notions of what was possible in their own learning.

\section{Data analysis}

We transcribed interview data and then uploaded it to a file sharing system. The data was then compiled into one file and uploaded to MAXQDA (data analysis software). We then read all the data files and made notes about preliminary patterns and possible themes. First author then compiled an initial list of themes, which was discussed with coauthors in a 90-minute dialog/conversation about initial reactions to the data. We then determined the data lent itself to thematic coding (e.g., themeing the data) (Saldaña, 2015) and first author completed thematic coding of the data in MAXQDA according to the pre-determined thematic codes, but also adding in-vivo coding when new themes were determined. Some of these thematic codes included "Home languages as resources (or not)", and included examples such as "I don't really use Nuer at school". Another code was "Navigating ELL" which included examples such as "I don't know the system". After the first cycle of coding in which 11 codes were determined, we discussed how many of the codes overlapped and brainstormed themes that would merge the overlapping codes and still allow us to answer our research questions. Next, we narrowed the themes down to wider semiotic processes involved in language differentiation and identity (markedness, iconicity, and erasure as described in our Theoretical Framework section). In addition, we included a fourth theme of language as a resource (Ruiz, 1984), in regards to discussions of multilingual pedagogies that came up in the data. In the next section, we describe the themes, providing examples from the data followed by our analysis, which draws heavily from theories introduced earlier in our paper.

\section{Findings and discussion}

\section{Markedness}

It is clear across interviews in our data, that contrary to many other places in world, in much of the United States (and especially where the 
participants for this study are located), being multilingual is marked. As noted in the literature review, this multilingualism is often invisible, especially when learners are proficient speakers of the dominant language and not identified as needing language support. However, sometimes multilingualism of learners is noticed (due to learners looking or sounding different from other students or both), and when it is, they are seen as unusual or distinct from other learners (i.e. "subject-as-seen" and "subject-as-heard" axes (Crump, 2014, p. 217). Being marked was seen positively by some of the participants, as in this example from Elena, who is White:

$\mathrm{R}^{6}$ : $\quad$ Do you think your teachers care about the fact that you speak other languages? Do they think of this as an achievement?

Elena: Uh, yeah. So-Some of them do, some of them think it's really cool.

R: $\quad$ Have they told you that? How do you know that?

Elena: Yes. Um, one of them- quite of few of them have told me that- how it's, uh, kind of special to be able to learn another language.

R: $\quad$ And how does that make you feel?

Elena: Special. ${ }^{7}$

However, for some of the participants, markedness is not always a good thing, as Aol (who is Black) points out in this excerpt. Below, she notes how on the "subject-as-heard" axes (Crump, 2014, p. 217), she is seen as different, and sometimes this bothers her

R: How do you feel when you speak Nuer?

Aol: I like it. Its unique. It's different from everyone else's.

R: $\quad$ How does being different from everyone else make you feel?

Aol: Sometimes it is like, cool, and it's like nice, but other times it's like the odd one out, so you stick out [more] than everyone else. Sometimes I don't like that.

6. $\mathrm{R}=$ Researcher.

7. Words bolded by the authors identify elements of focus in the analysis and discussion. 
Again, in this excerpt from Carina's interview, she notes that while she appreciates the efforts of some of her teachers to make her feel special, as a teenager, it is not always a good thing to be singled out as different in front of your peers:

Carina: I was like spoke French, and then, my teachers will always feel excited, and every time someone will come she would be “Oh really, this student speaks French!" I mean, it's nice but ...

R: $\quad$ She was trying to make you feel good.

Carina: Yeah, she was trying to make me feel comfortable, but after a while, it just kind of, I just felt a little uncomfortable.

R: $\quad$ Were you embarrassed?

C: $\quad$ Not necessarily embarrassed, I just ....

R: You just didn't want the attention on you.

C: $\quad$ Yeah, because then everyone is like "oooh she speaks French", and then they all turn around and look at me.

These excerpts illustrate how discourse on language often has a racializing function (Shuck, 2006, p. 260). Interestingly, while Elena is White, Carina and Aol are Black, hence their multilingualism is raced and therefore treated and viewed differently. It appears that through the ways they are racialized in addition to being viewed as multilingual learners, they are marked in a variety of ways, which sometimes proves to be too much. This is true, especially because they are teenagers, simultaneously dealing with the normal adolescent pressure to fit in. Below, Carina demonstrates another way in which she is marked, through her cultural and geographical origin, which again forces her to be called out and results in an embarrassing situation as she explains below, when talking about her music class:

Carina: Yeah. So, then we learned that a lot of Africans are great at playing the drums. I'm not!

R: (laughing)

Carina: But it's ok, I can always learn. She [the teacher] told everyone ... so they were like "oooh, she must be good at playing the drums". 
R: $\quad$ Oh, because that's what they learned that West Africans are good at drums ...

Carina: Yeah ... So ...

R: $\quad$ They all expected you to play?

Carina: Exactly! I am sitting there, and I'm just like ... No!!! (laughs) ... I can always learn, but I am not an expert. They were like "come on, you can do it!" And I'm like ... . It's kind of a lot of pressure because everyone else is watching you, and they're waiting for you to do something so amazing.

Later in the interview when the researcher asks what Carina would have preferred the teacher to have done in that situation, she comments that she should have said ...

Carina: “Do you like to play drums?” instead of saying you're from West Africa ... I think teachers should ask students first. Don't just apply stereotypes.

Carina illustrates an important aspect of how she is racialized in the classroom with the kind of racist discourse grounded in broad stereotypes that multilingual Students of Color may encounter. All of the students discussed ways their multilingualism marked them, but only the White student shared an experience where that marking was positive. Both of the Students of Color highlighted here illustrated how race and language worked in the classroom to mark them in ways they found uncomfortable or that were clearly racist.

The examples in this section provide student perspectives that could be useful for teachers to understand. Specifically, teachers need to recognize how they may participate in marking students regarding race and language, or at the intersection of both. It is especially important to attend to the way language is raced in these circumstances and how instances of multilingualism carry more or less social value when they are linked to racialized bodies experiencing varying levels of power and prestige due our racial hierarchies in society. Overall, we suggest that teachers work collaboratively with students in strong learning communities to avoid negative raciolinguistic marking. We now turn to iconicity. 


\section{Iconicity}

As we mentioned earlier, iconicity is when a sign physically resembles what it is representing, or in the case of language, when an expression or way of speaking marks a speaker as being from a particular social group or geographic area. In the case of the participants, because languages are associated with nations, and often knowledge by their teachers and peers of differences between languages is limited, learners like Amanda (from Brazil) can suffer from being metonymically (through relatedness to Spanish) associated with Spanish speakers. This is because people not familiar with Portuguese or Spanish cannot always tell the difference between the two languages or between names in Portuguese versus names in Spanish. Hence, for Amanda, who is not physically marked as being different from most of her peers, or from other Latinx students in her school, she is frequently frustrated by being assumed to speak Spanish. Below she discusses whether her teachers know she is from Brazil and speaks Portuguese:

Amanda: See, that's the thing, they don't know I'm from Brazil. They see that I have a different last name. But, lots of people from South America or Central America have difficult last names and also, students who are Americans, but their parents are from Central America also have difficult last names, so I think they expect us, everyone to be kind of different, but they don't see me as, oh, she's Amanda from Brazil. They just notice my accent and then they go, you're from a different country. Yes, I'm from Brazil, oh "What do you speak, Spanish?", NO, I speak Portuguese!

In the above example, Amanda demonstrates how discursive processes construct a speaker's "Whiteness and nativeness in English as unmarked and normal", whereas nonnative speakers of English are marked as nonwhite and foreign (Shuck, 2006, p. 259). In the process of noticing her "accent", Amanda's teachers accurately conclude she originates from a different country, constructing race/ethnicity through how she sounds (Crump, 2014; Roth-Gordon, 2016), 
and effectively producing the opposite of indexical bleaching. Indexical bleaching refers to the "deracializing and often dehumanizing process” that occurs when students' names are anglicized or carelessly mispronounced due to prevailing language ideologies (Bucholtz, 2016, p. 286).

We believe that what occurred with Amanda is a similar process, but instead of deracializing, it racializes her as Latina, and carries with it the discriminating residue applied to Spanish speakers. Because of her accent and Latina sounding name, she is categorized as Latina, and by metonymy, as a Spanish speaker. Even though many Brazilians do not identify as Latinx, but rather, Brazilian, they are lumped into the one category (much as people from India, Sri Lanka, Nepal and China are referred to as "Asians") [Lo, 2016]) and hence through iconicity, she is placed in the same racial/ethnic category as Spanish speakers whether she views herself as such or not. As such, connections between language, national origin, and race are naturalized (Shuck, 2006, p. 259). As Mitchell (2013, p. 351) states, "Languages are iconic of the people that speak them." In Amanda's case, even though physically, she is not necessarily identifiable as Latina, her last name, accent, and its proximity to Spanish allow her to be associated with Spanish speakers. In the United States, due to systemic discrimination against Spanish speakers, speaking Spanish immediately results in racialization, and negative assumptions associated with Spanish speakers such as immigration status, etc.

In the case of Santiago, whose parents are of Mexican origin, but whose dominant language is English, his manner of speaking is not iconic of Spanish speakers (in the sense that he sounds like all his other classmates), however, he says that his teachers "can see that he is Mexican." What he means is that in the eyes of his teachers, his physical characteristics are iconic for the social group to which he belongs, regardless of whether he speaks Spanish, whether he is classified as ELL, or through his name and physical appearance, he is identified as Mexican. This reveals how his racial(ized) identity intersects with his linguistic identity (particularly in terms of the way his teacher views him) (Crump, 2014).

As opposed to cases of multilingual learners such as Elena, that come from European backgrounds and are told they are "special" for being able to speak another language, this has not been the case for 
Santiago. Below, Santiago's mom points out what teachers should know about her son and others like him.

\section{I think they should realize that speaking another language is an asset, not a problem ... And uh, yeah, [not] be calling parents, telling them that, I think your son or daughter is not advancing in my class because she or he speaks another lan- guage in home and because some ... teachers do believe that that's a problem and I don't think it is a problem at all.}

The belief of the teacher reported by Santiago's mom is not uncommon, and much research has previously reported the erroneous perception that speaking a different language at home causes problems for learning in school (Briscoe, 2014; Menken, 2013; Shim, 2014). Deficit perspectives like these are especially harmful when combined with the metonymical process in which Spanish speakers become iconic for migrants/migration, and in the current climate in which discrimination against Latinx populations has increased (Beirich, 2019). Thus, despite the fact that Santiago's English is not identifiable as different from his peers, because of the iconicity of his physical appearance, name, and home language, he is categorized in this group and receives negative consequences because of it. As such, in the iconicity of multilingualism among our participants, race plays a clear and central role in impacting perceptions of students in terms of multiple aspects of their identity including their national origin as well as ability in the classroom.

\section{Erasure}

Erasure is when ideology renders people, actions, or events invisible (Gal \& Irvine, 1995). In the US when parents register children for schools, they are often required to identify (by checking a box) if their child speaks a language other than English at home. If they check "yes", rather than simply explaining what experience the child has had with English and whether or not they will need any extra help, students are immediately tested for English proficiency and then placed (or not placed) in English language development programs based on this sole indicator. This systematic procedure is based on a 
monolingual ideology that contains a deficit perspective of multilingualism, assuming that students who speak other languages will need help in English, although this is not always the case. As a result, many parents are faced with the difficult choice of whether to reveal if their child speaks another language at home (and hence, force them to undergo testing, and perhaps placement in an "ELL" program when the parent knows they don't need it), or just check the "no" box, and have their child's multilingualism go under the radar. On the other hand, if students' test scores do not indicate they need English support, or if the parents opt out of English support programs, they cannot receive (official) help even if they might still need it. One might wonder in these cases why a parent would choose not to get help for their child.

As we see from our next example, often the decision of whether to be tested (and hence possibly placed in a program) can cause family upheaval, as it can involve changing schools and separating siblings. Below, Tobias's mother discusses how they made the decision to not receive English support services for Tobias since his test results showed he was on the border between needing services or not:

We were trying to figure out where to buy a house and were like, wait, so we don't know which school he's going to go to and all of our kids might go to different schools depending on what's happening in qualifying and disqualifying for services repeatedly ...

Basically, we were hoping that he would not qualify for services because we just didn't want the whole upheaval. He went in for this test and they said basically he was on the edge enough that they were like, "what would you prefer?" and we were like, we would prefer it if he did not qualify for the services and so he was able to stay in school.

So that was kind of a bummer because I wouldn't have minded him like having a little bit of help, you know what I mean, subsequently. But at that point it was like, nope. You're out of the system. You don't exist.

The above example illustrates how students like Tobias who could have used the extra help did not get it because his parents chose not to complicate their family life (by having to move schools or houses). 
In addition, in the case of other multilingual students who are dominant in English but speak other languages as well, the way the system is set up does not leave the option for parents to mark "yes" to their child speaking another language at home, but "no" to whether they want their child tested. As a consequence, their multilingualism is erased from the system, not counted in school census reports, and generally ignored unless parents or learners make it known to teachers.

Another example of erasure related to language is in the case of non-European languages. Because of the semiotic association of language with power (e.g., widely spoken languages are widely spoken for a reason, usually related to some form of colonization or subjugation of people), as well as the racial associations of the bodies that typically use particular languages, certain languages have more prestige than others. Often, languages spoken that are not common languages of prestige (often due to racialized perspectives of the speakers of those languages) are not recognized or valued (or remembered) in the larger society. But also, as noted by Bourdieu and Nice (1977), "the language of authority never governs without the collaboration of those it governs, without the help of social mechanisms capable of producing this complicity" (p. 164). Hence, often speakers of these languages do not bother to mention them, because they are complicit in the fact that these languages don't count, or are not important. This is because they have grown up with this underlying ideology and habitus which has permeated their thinking. In the example below, through "deep interviewing" (Denzin, 2001), the researcher attempts to get the participants to think about these other languages they speak and why they don't mention them to teachers:

R: $\quad$ Ok, so [teachers] just know about French, they don't know about these other languages. What do you think they don't know about the other languages?

$\mathrm{M}^{8}$ : $\quad$ They don't know she has other languages apart from French and English.

R: $\quad$ But why not?

M: $\quad$ Because we did not really discuss that with them, and they never asked neither.

8. $\mathrm{M}=$ Carina's mother, but in general in this paper, $\mathrm{M}=$ Mother of participant in focus. 
R: $\quad$ They didn't ask ... But when they asked you what other languages she knew, how come you didn't you say some of those other ones?

M: Well, they didn't really ask me the question. (Laughter)

R: $\quad$ They didn't ask you what languages she knew?

Carina: No.

R: $\quad$ OK so they just assumed French?

M: $\quad$ When we filled the forms, ... . And I think ... from there that they know, and she also told some of them that she knew some French.

R: $\quad$ French?

M: That's all.

R: $\quad$ So, why didn't you tell them anything about the other languages?

Carina: I do sometimes, but then they forget and just mostly focus on French because that's what is usually - French

is almost like known by everyone, so it [is] easy.

R: $\quad$ So you know that when you tell people, they will remember, they will understand; but if you tell people like Buamu, Wolof ...

M: $\quad$ Uh huh ... Dioula ...

R: $\quad$ They will be like, what?

Carina: Yeah ... they will forget and usually they don't talk about those other languages and they will say, "Oh she speaks French and English and then a few other languages.

Above, Carina notes how languages she knows such as Dioula, Buamu and Wolof (from her time living in Senegal) are erased by the phrase a few other languages while French is remembered and named, foregrounding speakers of these languages as "normal" while other identities are rendered invisible or inferior. There are obvious raciolinguistic ideologies at play when the named and honored language is the one associated with a predominantly White population and the erased and under acknowledged languages are associated with predominantly Black populations. Kerfoot and Tatah (2016) refer to this as orders of visibility, meaning, "the shared frames of reference and meaning-making practices that construct, legitimate and obscure relations of power, foregrounding certain modes of knowing, being, and 
saying, and rendering others invisible" (p. 2). While not specifically called out in this quote, race plays a central role in constructing the order of visibility. The "deep interviewing" technique applied here by the researcher was meant to counter this erasure of Carina's other languages, and to awaken the process of critical consciousness in her about this invisibility so that she might be able to advocate for her other languages to be resources in her learning later on.

\section{Languages as resources}

Research has established that teachers "should help learners become aware of and draw on their existing knowledge" (Haukås, 2016, p. 2), which includes knowledge of other languages. Because multilingual learners' prior knowledge is encoded in their home languages, building on this knowledge means linking school language concepts with the learner's cognitive schemata for their other languages (Cummins, 2009, p. 319). Despite this research, especially in cases where students are not identified as needing language support, teachers are often not aware or not able to understand how to make these connections for students among their languages. Moreover, a point not lost on our participants is that many of their teachers are monolingual, and hence often aren't familiar with the languages of the students (or with language acquisition in general) and so they don't feel confident using multilingual pedagogies or they haven't had training in how to use them (see Bruen \& Kelly, 2016 for some concrete strategies for doing this). As a result, while some of our participants noted that their teachers did try to incorporate their linguistic or cultural knowledge in their learning (e.g. Elena), systematically, across interviews, could not imagine what this could look like, although many noted that they thought it would be helpful.

In order to get participants to recognize the value in drawing on their home languages in their learning, we took advantage of "deep interviewing" techniques (e.g., Denzin, 2001) to give them some ideas so that they could use their own agency to help this to happen and hence improve their learning capacity. Moreover, we hoped that legitimizing students' home languages as cognitive tools within the classroom would challenge the subordinate status of some of our participants' languages (Cummins, 2009), affirming their identities and promoting their "identities of competence" (Manyak, 2004). We now provide an 
example from Carina's interview which shows her perceptions about teachers using her language/s as resources in the classroom, as well as how we tried to use the interviews to transform her thinking about the possibilities that this type of pedagogy affords.

R: $\quad$ Have your teachers ever tried to help you use your French to learn some of your other content like if anybody said, you know, you can read this about this information in Social Studies in French if you want?

Carina: No! They give it to me ... in English, like everyone else, so it is fair.

R: $\quad$ Oh, so that it's fair ... (laughter)

Carina: I think it's so that it is fair.

R: $\quad$ Do you think that's fair? (laughter)

Carina: Not everyone speaks my language ...

R: $\quad$ But I mean if you got it in French and they got it in English ...

Carina: Well ...

R: $\quad$ That would not be fair? ...

Carina: I don't know. It is kind ok, it is fair because I see a lot of. ...

R: $\quad$ Because you just said you feel more comfortable in French. Do you think it would be fair for you to be able to do some of your homework in a language you feel more comfortable with? ...

\section{Carina: Yeah, I like that.}

In this example, we see a transformative change in the participant in which she is beginning to disrupt her deeply ingrained language ideologies and habitus that position English as the ONLY language of instruction and naturalize its hegemony in schooling. In her brief interview period, she begins her journey to develop critical consciousness (Freire, 1974) which allows her to start seeing contradictions and consider actions that free herself from oppressive learning contexts. Initially, Carina believes it is fair for her to receive all information in English because this is what is available for all students. However, once she is pushed to consider that all students could have reading materials in languages they are most comfortable with (due to the internet 
and increased availability of multilingual resources), she begins to see that this is not only possible, but desirable.

A final example which demonstrates how transformative interviewing practices can help develop critical consciousness and agency for multilingual learners to create more equitable learning contexts for themselves comes from an interview with Meike. When asked about her teacher's recognition and valuing of her German background, Meike's response is that they don't care, but that she doesn't care either. Using “deep interviewing” techniques, the researcher tries to probe further and push back on this notion that she doesn't care, multiple times throughout the interview. Below, we include some excerpts:

R: What about your teacher? Does she know you speak German?

Meike: Yes, so sometimes we might be learning about ... sometimes for holidays ... like sometimes for holiday stuff, I get to tell about Christmas or Easter in Germany, but that's all. That's really all. Nobody really cares. I'm just a kid like everybody else, and nobody really cares. I don't really care.

R: $\quad$ I mean, think it's interesting that you say you don't really care. Do you say that because you don't want to be perceived of as different from the other kids?

Meike: Oh, that doesn't matter. It's just no one really cares. No one really notices. It doesn't really matter to anyone. That's what I mean. It doesn't really matter! I like being German, but it doesn't really matter.

Later in the interview ...

R: $\quad$ So, I understand what you're saying about it doesn't really matter, but ...

Meike: It doesn't matter! I like being German, but it doesn't really matter. No one really cares about it. It doesn't matter!

Again, later in in the interview ... 
R: $\quad$ Oh, ok. I'm curious because I think it's really special when kids get to speak more than one language. It's a really ... it's kind of an awesome gift because you ...

Meike: I like being German! And I think it's awesome too, but it doesn't really matter. When I'm in class, or at school, I'm just like everyone else.

As shown above, Meike does not change her attitude or beliefs about her multilingualism and schooling. After multiple places in which the researcher tries to point out ways in which her teachers could include her language/culture in classroom learning, she still contends that it doesn't matter. Although the above example illustrates that we were not successful in all of our attempts at awakening critical consciousness in our participants, overall, they reported being happy that they are multilingual and that it is something they value in themselves. They also reported wishing that their multilingualism would be valued as a resource in school in a variety of ways, though, many of them realized the challenge of integrating their multilingualism into such English only spaces.

\section{Implications}

Findings revealed that students had different experiences depending on race/ethnicity, and their home languages. Markedness and iconicity played a significant role in racialization, and categorization of learners because of the way that learners are positioned as being physically or auditorily (e.g., accent) different, and what these differences indexed. For example, while Elena's teachers made her feel special for knowing Russian, Santiago's teachers blamed his problems in school on his speaking Spanish at home. In the case of Amanda, her name and geographical origin (South America) caused her to be categorized as Spanish-speaking, even though she was from Brazil. On the other hand, the semiotic process of erasure resulted in student languages (and identities as multilinguals) often becoming invisible to teachers (and others), in cases like Tobias, because of ideologies that included deficit views of multilingualism. For Carina, languages connected to her home and her identity were effectively erased because of language 
hegemony which results in languages without power or prestige (intersected with race) being ignored or not remembered.

In regards to the role that race/ethnicity plays in the experiences of multilingual learners, implications of this study are that teachers and teacher educators must do more to challenge and disrupt the racing of language. Culturally sustaining pedagogy which "seeks to perpetuate and foster - to sustain - linguistic, literate, and cultural pluralism as part of the democratic project of schooling" could be one way to challenge the racing of language in teacher education programs (Paris, 2012, p. 93). In addition, teacher education programs need to help teachers develop racial literacy (Sealey-Ruiz, 2017) in order for them to recognize the way in which racist discourse of the public sphere and past ideologies they hold about immigration (that they connect to race/ethnicity and language) interact with their own teaching.

In answer to how learners perceive of the way that schools both acknowledge and draw on their multilingualism in learning, our study presents a resounding "needs work" in this area. Although some participants acknowledged that some of their teachers recognized and valued their multilingualism, this was not done in a systemic way, and in most cases constituted of only a small percentage of their teachers. Moreover, participants had to be pressed to imagine what multilingual pedagogies could look like, due to their school socialization that shaped their ways of thinking about language (i.e., monolingual ideologies). The implications of these findings point to the need for more explicit training on translanguaging theory and pedagogy (García \& Kleyn, 2016) that could be used to teach preservice teachers (and as professional development for in-service teachers) how to draw on the linguistic resources of their students instead of erasing them. Coupled with strong racial literacy development, such learning opportunities could disrupt the negative raciolinguistic ideologies our participants exposed in their schooling experiences as multilingual students.

\section{Limitations}

Although our study findings cannot be generalized due to the small number of participants, they do provide clear evidence of variation among multilingual learner experiences. We hope that others will 
continue this work exploring multilingual populations in the US, but we also encourage more research to study multilinguals and their schooling experiences in other countries. In addition, although we only included learners ages 9-17, we recognize that younger learners also might have poignant and interesting insights to bring to this subject so we suggest that further research include this age group as well. Furthermore, we recognize that in the course of one interview, it is not possible for someone to fully develop critical consciousness, as such we realize that our paper does not track this development since it would need to be done over time. However, what we believe this study does do is show techniques in getting this started, and a few places where it does or does not have an effect on the thinking of the participant, which may lead to future development of critical consciousness. In the future, we hope to continue this work with a longitudinal study that re-visits participants later in their schooling trajectory. We also look forward to focusing more on the parents of the learners in order to understand their point of view.

\section{Conclusion}

This study explored the experiences of multilingual learners NOT identified as "ELL" in US K-12 schools seeking to understand how they varied depending on a range of factors such as race/ ethnicity, language, and language ideologies/attitudes. Using “deep interviewing” strategies, we exposed the racializing function of language for our students while noting the central role that semiotic processes of markedness, iconicity, and erasure played in their schooling experiences. In addition, while we were disappointed that overall, our participants reported not utilizing their linguistic resources in their learning, transformative interviewing provided a promising counter strategy to disrupt habitus ingrained in learners. This then helped begin the process of awakening their critical consciousness to allow them to question their ingrained beliefs (Wolfram \& Schilling-Estes., 2006) about the way school is, and should be, with respect to language.

In conclusion, because theoretical research is a form of social practice in which we aim to "know something in order to do something", we encourage more research that learns from participants but doesn't 
just "leave the world as it is" (Eco, 1976, p. 29). Rather, it helps them begin to recognize their own agency in creating more equitable learning contexts for themselves.

\section{References}

Alim, H. S., Rickford, J. R., \& Ball, A. F. (eds). (2016). Raciolinguistics: How language shapes our ideas about race. New York, NY: Oxford Press.

Bailey, E. G., \& Marsden, E. (2017). Teachers' views on recognising and using home languages in predominantly monolingual primary schools. Language and Education, 31(4), 283-306.

Baker-Bell, A. (2018). "I can switch my language, but I can't switch my skin”: What teachers must understand about linguistic racism. In E. Moore, A. Michael, M. W. Penick-Parks, G. E. Singleton, \& H. Hackman (Eds.), The guide for White women who teach Black boys: Understanding, connecting, respecting (pp. 97-107). Thousand Oak, CA: Corwin Press.

Beirich, H. (2019, February 20). The year in hate: Rage against change. Southern Poverty Law Center. Retrieved from https://www.splcenter.org/fighting-hate/ intelligence-report/2019/year-hate-rage-against-change

Bourdieu, P. (1994). Structures, habitus, power: Basis for a theory for symbolic power. In N. B. Dirks, G. Eley, \& S. B. Ortner (Eds.), Culture/power/history: A reader in contemporary social theory (pp. 155-199). Princeton, NJ: Princeton University Press.

Bourdieu, P., \& Nice, R. (1977). Outline of a theory of practice (Vol. 16). Cambridge: Cambridge University Press.

Briscoe, F. M. (2014). “The biggest problem”: School leaders' covert construction of Latino ELL families-Institutional racism in a neoliberal schooling context. Journal of Language, Identity \& Education, 13(5), 354-373. doi:10.1080/153484 58.2014.958041

Brooks, M. D. (2015). “It's like a script”: Long-term English learners' experiences with and ideas about academic reading. Research in the Teaching of English, 49(4), 383-406.

Brooks, M. D. (2019). A mother's advocacy: Lessons for educators of long-term EL students. In H. A. Linville \& J. Whiting (Eds.), Advocacy in English language teaching and learning (pp. 175-189). London, UK: Taylor and Francis.

Bruen, J., \& Kelly, N. (2016). Language teaching in a globalised world: Harnessing linguistic super-diversity in the classroom. International Journal of Multilingualism, 13(3), 333-352. doi:10.1080/14790718.2016.1142548

Bucholtz, M. (2016). On being called out of one's name: Indexical bleaching as a technique of deracialization. In H. S. Alim, J. R. Rickford, \& A. F. Ball (Eds.), Introducing raciolinguistics: How language shapes our ideas about race (pp. 273-290). Oxford: Oxford University Press. 
Chapman, T. K. (2007). Interrogating classroom relationships and events: Using portraiture and critical race theory in education research. Educational Researcher, 36(3), 156-162. doi:10.3102/0013189X07301437

Chhuon, V., Hudley, C., Brenner, M. E., \& Macias, R. (2010). The multiple worlds of successful Cambodian American students. Urban Education, 45(1), 30-57. doi:10.1177/0042085909352583

Crump, A. (2014). Introducing LangCrit: Critical language and race theory. Critical Inquiry in Language Studies, 11(3), 207-224. doi:10.1080/15427587.20 14.936243

Cummins, J. (2000). Language, power, and pedagogy: Bilingual children in the crossfire (Vol. 23). Bristol, UK: Multilingual Matters.

Cummins, J. (2009). Multilingualism in the English-language classroom: Pedagogical considerations. TESOL Quarterly, 43(2), 317-321. doi:10.1002/ tesq.2009.43.issue-2

de Jong, E. J. (2013). Policy discourses and U.S. language in education policies. Peabody Journal of Education, 88, 98-111. doi:10.1080/0161956X.2013.752310

Denzin, N. K. (2001). The reflexive interview and a performative social science. Qualitative Research, 1(1), 23-46. doi:10.1177/146879410100100102

Eco, U. (1976). A theory of semiotics. Bloomington: Indiana University Press.

Flores, N., \& Rosa, J. (2015). Undoing appropriateness: Raciolinguistic ideologies and language diversity in education. Harvard Educational Review, 85(2), 149171. doi:10.17763/0017-8055.85.2.149

Fránquiz, M. E., \& de la Luz Reyes, M. (1998). Creating inclusive learning communities through English language arts: From” chanclas" to" canicas". Language Arts, 75(3), 211-220.

Freire, P. (1974). Conscientisation. CrossCurrents, 24(1), 23-31.

Gal, S., \& Irvine, J. T. (1995). The boundaries of languages and disciplines: How ideologies construct difference. Social Research, 62(4), 967-1001.

García, O. (2009a). Education, multilingualism and translanguaging in the 21st century. In T. Skutnabb-Kangas, R. Phillipson, A.K. Mohanty, \& M. Panda (Eds.), Social justice through multilingual education (pp. 140-158). Bristol, UK: Multilingual Matters.

García, O. (2009b). Emergent bilinguals and TESOL: What's in a name? Tesol Quarterly, 43(2), 322-326. doi:10.1002/tesq.2009.43.issue-2

García, O., \& Kleyn, T. (2016). Translanguaging theory in education. In O. García \& T. Kleyn (Eds.), Translanguaging with multilingual students: Learning from classroom moments (pp. 9-33). New York, NY: Routledge.

García, O., Johnson, S. I., Seltzer, K., \& Valdés, G. (2017). The translanguaging classroom: Leveraging student bilingualism for learning. Philadelphia, PA: Caslon.

García, O., \& Kleifgen, J. A. (2010). Educating emergent bilinguals: Policies, programs, and practices for English language learners. New York, NY: Teachers College Press. 
García, O., \& Sylvan, C. E. (2011). Pedagogies and practices in multilingual classrooms: Singularities in pluralities. The Modern Language Journal, 95(3), 385-400. doi:10.1111/modl.2011.95.issue-3

González, N., Moll, L. C., \& Amanti, C. (Eds.). (2006). Funds of knowledge: Theorizing practices in households, communities, and classrooms. London, UK: Routledge.

Greenfield, D. (2010). "When I hear Afrikaans in the classroom and never my language, I get rebellious": Linguistic apartheid in South African higher education. Language and Education, 24(6), 517-534. doi:10.1080/09500782.20 10.502969

Gutiérrez, K. D., \& Jaramillo, N. E. (2006). Chapter 9: Looking for educational equity: The consequences of relying on Brown. Yearbook of the National Society for the Study of Education, 105(2), 173-189. doi:10.1111/j.1744-7984.2006.00081.X

Haukås, Å. (2016). Teachers' beliefs about multilingualism and a multilingual pedagogical approach. International Journal of Multilingualism, 13(1), 1-18. doi: 10.1080/14790718.2015.104196o

Hill, J. H. (2010). Language, race, and white public space. In L. Wei (Ed.), Bilingualism and multilingualism: Critical concepts in linguistics (Vol. 3, pp. 394-409). London, England: Routledge.

Janzen, J. (2008). Teaching English language learners in the content areas. Review of Educational Research, 78(4), 1010-1038. doi:10.3102/0034654308325580

Kerfoot, C., \& Tatah, G. (2016). Constructing invisibility: An immigrant learner in South Africa. Working Papers in Urban Languages and Literacies, 192, 1-25.

Kiramba, L. K. (2017). Multilingual literacies: Invisible representation of literacy in a rural classroom. Journal of Adolescent \& Adult Literacy, 61(3), 267-277. doi:10.1002/jaal.69o

Kiramba, L. K, \& Harris, V. J. (2019). Navigating authoritative discourses in a multilingual classroom: Conversations with policy and practice. TESOL Quarterly, 52(2), 482-513. doi:10.1002/tesq.493

Liddicoat, A. J., \& Curnow, T. J. (2014). Students' home languages and the struggle for space in the curriculum. International Journal of Multilingualism, 11(3), 273-288. doi:10.1080/14790718.2014.921175

Lippi-Green, R. (2012). English with an accent: Language, ideology and discrimination in the United States. London, UK: Routledge.

Lo, A. (2016). Suddenly faced with a Chinese village. In H. S. Alim, J. R. Rickford, \& A. F. Ball (Eds.), Introducing raciolinguistics: How language shapes our ideas about race (pp. 97-102). Oxford: Oxford University Press.

Lucas, T., Villegas, A. M., \& Freedson-Gonzalez, M. (2008). Linguistically responsive teacher education: Preparing classroom teachers to teach English language learners. Journal of Teacher Education, 59(4), 361-373. doi:10.1177/0022487108322110

MacSwan, J. (2017). A multilingual perspective on translanguaging. American Educational Research Journal, 54(1), 167-201. doi:10.3102/o002831216683935 
Manyak, P. C. (2004). "What did she say?”: Translation in a primary-grade English immersion class. Multicultural Perspectives, 6(1), 12-18. doi:10.1207/ S15327892mcpo601_3

Matsuda, M., Lawrence, C., Delgado, R., \& Crenshaw, K. W. (1993). Words that wound: Critical race theory, assaultive speech and the first amendment. Boulder, CO: Westview Press.

Matsuda, M. J. (1991). Voices of America: Accent, antidiscrimination law, and a jurisprudence for the last reconstruction. The Yale Law Journal, 10o(5), 13291407. doi:10.2307/796694

Menken, K. (2013). Restrictive language education policies and emergent bilingual youth: A perfect storm with imperfect outcomes. Theory Into Practice, 52(3), 160-168. doi:10.1080/00405841.2013.804307

Menken, K., Kleyn, T., \& Chae, N. (2012). Spotlight on "long-term English language learners": Characteristics and prior schooling experiences of an invisible population. International Multilingual Research Journal, 6(2), 121-142. doi:10.1080/19313152.2012.665822

Mitchell, K. (2012). English is not all that matters in the education of secondary multilingual learners and their teachers. International Journal of Multicultural Education, 14(1), 1-21. doi:10.18251/ijme.v1411.495

Mitchell, K. (2013). Race, difference, meritocracy, and English: Majoritarian stories in the education of secondary multilingual learners. Race Ethnicity and Education, 16(3), 339-364. doi:10.1080/13613324.2011.645569

Orellana, M. F., \& Reynolds, J. F. (2008). Cultural modeling: Leveraging bilingual skills for school paraphrasing tasks. Reading Research Quarterly, 43(1), 48-65. doi:10.1598/RRQ.43.1.4

Paris, D. (2012). Culturally sustaining pedagogy: A needed change in stance, terminology, and practice. Educational Researcher, 41(3), 93-97. doi:10.3102/0013189X12441244

Park, J. Y. (2013). Becoming academically literate: A case study of an African immigrant youth. Journal of Adolescent and Adult Literacy, 54, 298-306. doi:10.1002/jaal.241

Reyes de la Luz, M. (2012). Spontaneous biliteracy: Examining Latino students' untapped potential. Theory into Practice, 51(4), 248-255. doi:10.1080/004058 41.2012 .726052

Rosa, J. (2019). Looking like a language, sounding like a race: Raciolinguistic ideologies and the learning of Latinidad. USA: Oxford University Press.

Roth-Gordon, J. (2016). From upstanding citizen to North American rapper and back again: The racial malleability of poor male Brazilian youth. In H. S. Alim, J. R. Rickford, \& A. F. Ball (Eds.), Introducing raciolinguistics: How language shapes our ideas about race (pp. 97-102). Oxford: Oxford University Press.

Ruiz, R. (1984). Orientations in language planning. NABE journal, 8(2), 15-34. doi :10.1080/08855072.1984.10668464

Saldaña, J. (2015). The coding manual for qualitative researchers. London, UK: Sage. 
Sealey-Ruiz, Y. (2017). Talking race, delving deeper: The racial literacy roundtable series at Teachers College, Columbia University. In B. Picower \& R. Kohli (Eds.), Confronting racism in teacher education: Counternarratives of critical practice (pp. 127-132). New York, NY: Routledge.

Shim, J. M. (2014). A Bourdieuian analysis: Teachers' beliefs about English language learners' academic challenges. International Journal of Multicultural Education, 16(1), 40-55. doi:10.18251/ijme.v16i1.783

Shuck, G. (2006). Racializing the nonnative English speaker. Journal of Language, Identity, and Education, 5(4), 259-276. doi:10.1207/s15327701jlieo504_1

Spack, R. (1997). The rhetorical construction of multilingual students. TESOL Quarterly, 31(4), 765-774. doi:10.2307/3587759

Stake, R. E. (2000). Case studies. In N. K. Denzin \& Y. S. Lincoln (Eds.), Handbook of Qualitative Research (2nd ed., pp. 435-454). Thousand Oaks, CA: Sage.

Van der Walt, C. (2015). Bi/multilingual higher education. In W. E. Wright, S. Boun, \& O. García (Eds.), The handbook of bilingual and multilingual education (pp. 334-371). Hoboken, NJ: John Wiley and Sons.

Velázquez, I. (2018). Household perspectives on minority language maintenance and loss: Language in the small spaces. Multilingual Matters.

Visser, G. (2000). In other worlds: On the politics of research in a transforming South Africa. Area, 32(2), 231-235. doi:10.1111/area.2000.32.issue-2

Waugh, L. R. (1982). Marked and unmarked: A choice between unequals in semiotic structure. Semiotica, 38(3-4), 299-318. doi:10.1515/ semi.1982.38.3-4.299

Wolfram, W., \& Schilling-Estes., N. (2006). American English: Dialects and variation (2nd ed.). Malden, MA: Blackwell.

\section{Appendix. Interview protocol}

(1) What is your name, age, grade level (if applicable) and where do you live now?

(2) What languages do you speak, and for each, describe how well you speak, read, write, understand the language according to these levels: beginner, intermediate, proficient, near-native and/native speaker.

(3) Describe in detail your language history. Which languages do you speak? When did you learn each language and how?

(4) Describe in detail which countries you have lived in for which reasons and for how long.

(5) Describe what you do to maintain and develop each language you know.

(6) Which language do you feel you express yourself best in speaking, reading, writing, and understanding?

(7) Do you think your child's (or your, if talking to child) teachers know the information you have just provided about your (or your child's) language and cultural background?

(8) Do you think they should know? 
(9) Do your teachers ever ask you about your languages or cultural background?

(10) Do your teachers ever ask you to do research, readings, writing or oral activities utilizing your other languages?

(11) Does your teacher recognize at all your other languages and help you use them to learn? If yes, explain.

(12) Do you think your teachers could utilize your languages in some way?

(13) Do you think your teachers care about the other languages you speak or recognize this as an achievement? Why or why not?

(14) Have you ever had any problems or situations arise due to the other languages you speak?

(15) Have you ever been asked to translate for other students or help them in any way because of the languages you speak? Explain.

(16) What do you think teachers should know about working with students like you (or your child), that speak English well, but also know other languages?

(17) Do you think there is a place for your languages other than English in schools?

(18) Do you see any evidence of your languages in the school environment?

(19) Is there anything else you would like me to know about your school experiences that you think could help other learners like you (or your child)? 